\title{
The Effect of Technology Readiness on Technology Acceptance in Using Services Delivery of Academic Information System
}

\author{
Rorim Panday \\ Bhayangkara Jaya University,Management, Jakarta,Indonesia \\ indripan@gmail.com
}

\begin{abstract}
IT is part of the system of input-process-output of an operational system of an activity / organization. IT is expected to improve the effectiveness and efficiency. With the IT system, it is expected that the results are more accurate, delivered quickly and satisfactorily. However, IT will still depend on the people who use / operate it. A reality, even though already using IT systems, service still slow. This can be caused by personal factors of people who use or are operationalizing, known with the level of technology readiness. In addition, it can also be influenced by the level of acceptance of the technology of people who use / operate it. This study will reveal how the influence and relationship of Technology Radiness to Technology Acceptance in the use of the Academic Information System (AIS) from the ABC university in Jakarta. The study sample as many as 285 people at random from AIS users, using a questionnaire that developed by Parasuraman and Davis. The analysis is developed using path analysis, and compute by AMOS 18. The results of this study indicate that, variable Optimism, Innovativeness, Discomfort and Insecutrity have positive effect on Perceived ease of use, indicated by the p-value less than 0.05 or the value of CR (Critical Ratio) is greater than two. Optimism variable does not provide significant effect on Perceived usefulness. Innovativeness and discomfort variables are significant positive effect on the variable Perceived usefulness, while variable Insecurity in significant negative effect on the variable Perceived usefulness. Variables Perceived ease of use, are significant positive effect on the variable Perceived usefulness. Variables Perceived usefulness and variables of Perceived ease of use are positive and significant effect on the variable Actual use. Of the 11 hypothesis 7 hypothesis proved while 4 hypothesis is not proven. Based on these results, the implications for management strategies discussed in this paper.
\end{abstract}

Keywords: Technology readiness, technology acceptance, perceived ease of use, perceived usefulness, actual use.

\section{Introduction}

Higher education is a place to produce human resources that have specific knowledge and skills. For that purpose required operations system as effective and efficient. Many management of higher education today are already using IT or ICT system. The use of ICT (Panday, 2015) at universities, namely for the management of higher education, such as the management of new student admission, academic management, financial management, asset management, and human resources management of the college. ICT systems for the management known as the Academic Information System(AIS). With this system the management of the college is expected to become more effective and efficient, both in kind of users such as students, faculties, parents, and relevant stakeholders, and in kind of management of the university. AIS makes such a fast moving information to anyone who needs it. AIS is part of the college operational system in order to improve effectiveness and efficiency.

AIS is built to meet the needs of universities as a provider for delivery education services, improve operation performance, enhance the quality of service, to increase 
competitiveness and quality in resulting human resources outcome, assist in data management such as student grades, subjects, the data of faculties as well as the administration staff, so that to be able to reduce time and operating costs. AIS also to serve the registration process and facilitate for student assignment given by the lecturer during the semester. Besides, with AIS more easy in preparing EPSBED (Evaluation Study Based on Self Evaluation Program) reports which must be submitted to the Higher Education each semester automatically. Some advantages of AIS among others; user friendly, in accordance with the needs of higher education, suppress and Web-Based Operating Costs / Network and can be developed consistently. For faculties and students, AIS created to help in the learning process, update the knowledge from the internet, support the Tridharma of Higher education, namely education and teaching, research and community service, so that the quality of learning and education for more better.

However, some of the lecturers and students are technology illiterate, because they had a little bit IT knowledge, so that readiness to use IT is also little. The impact of this less readiness, they do not use AIS for daily activities rightly for example in teaching learning. Most of them still using traditional manners, such as use the old text book, use white board to delivery the subject, or use ovehead projector. Actually AIS has already built in ABC campus. Therefore, it is very interesting this study was conducted to see how the readiness and the acceptance of faculties and students to use AIS for teaching-learning and administration. And how the effect of readiness to the acceptance of lecturer and student for that AIS technology? Next, how the intention of lecturers and student in using the AIS system. For all of those purposes, will be conducted the study at $\mathrm{ABC}$ higher education as once higher education in Jakarta.

\section{Review of Literature}

To support for this study, it is relevant to the theory of technology readiness (TR) which introduced by Parasuraman and technology acceptance model (TAM) which developed by Parasuraman and Davis. As we know, technology readines (TR) is refers to "people's propensity to embrace and use new technologies to accomplish goals in home life and at work" (Parasuraman, 2000, p. 308).

Technology readiness can be viewed resulting from four personality dimensions: optimism, innovativeness, discomfort, and insecurity. According to Parasuraman (2000) these personality dimensions affect people's tendency to embrace and use new technologies. In this respect optimism and innovativeness function as mental enablers, while discomfort and insecurity function as mental inhibitors to accept new technologies. TR is a combination of positive and negative technology-related beliefs. These beliefs are assumed to vary among individuals. Collectively, these coexisting beliefs determine a person's predisposition to interact with new technology (Parasuraman \& Colby 2001). The four dimensions of TR are: (Parasuraman, 2000).

- Optimism is defined as "a positive view of technology and a belief that offers people increased control, flexibility, and efficiency in their lives" (Parasuraman \& Colby, 2001, p. 34). It generally captures positive feelings about technology.

- Innovativeness is defined as "a tendency to be a technology pioneer and thought leader" (Parasuraman \& Colby 2001, p. 36). This dimension generally measures to what degree individuals perceive themselves as forefront.

- Discomfort is defined as "a perceived lack of control over technology and a feeling of being overwhelmed by it" (Parasuraman \& Colby 2001, p. 41). This dimension generally measures the fear and concerns people experience when confronted with technology. 
- Insecurity is defined as "distrust of technology and scepticism about its ability to work properly" (Parasuraman \& Colby, 2001, p. 44). This dimension focuses on concerns people may have in face of technology-based transactions.

Optimism and innovativeness are drivers of technology readiness. A high score on these dimensions will increase overall technology readiness. Discomfort and insecurity, on the other hand, are inhibitors of technology readiness. Thus, a high score on these dimensions will reduce overall technology readiness (Parasuraman, 2000). Results show that the four dimensions are fairly independent, each of them making a unique contribution to an individual's technology readiness (Parasuraman \& Colby, 2001).

Extensive multiphase research program in the United States has been done by Parasuraman (2000), and Tsikriktsis (2004) in Great Britain, related to the realibilty data for TR, with many respondents, resulting the same conclusion about ranging of cronbach value for reliabilty study of TR.

Another theory used in this study is the technology acceptance model (TAM), which introduced by Davis (1989, p. 320); In TAM there are two central determinants: Perceived usefulness, which refers to "the degree to which a person believes that using a particular system would enhance his or her job performance" (Davis, 1989, p. 320); and perceived ease of use, which refers to "the degree to which a person believes that using a particular system would be free of effort" (Davis, 1989, p. 320). TAM was designed specifically to explain computer usage behaviour. It is an adaptation of Fishbein and Azjen's (1975) theory of reasoned action (TRA), which has been successful in predicting and explaining behaviour in general (Malhotra \& Galletta, 1999; Yi \& Hwang, 2003).

Following the theoretical basis of TRA these perceived characteristics are expected to influence intensions to use a system, which in turn influence actual system usage (Davis et al., 1989). Furthermore, perceived ease of use is hypothesized to influence perceived usefulness. This hypothesis follows from the logic that improvements in ease of use of a system contribute to increased usefulness due to saved effort (Davis et al., 1989).

The TAM has received considerable support over the years. It has been validated over a wide range of systems, and perceived usefulness and perceived ease of use have proven to be reliable and valid cognitive dimensions (Burton-Jones \& Hubona, 2006; King \& He, 2006).

In this study used TRI integrated with TAM, which "people's propensity to embrace and use new technologies to accomplish goals in home life and at work" will predict to technology acceptance, and the next will influence to behavior intention which represent by actual use. The integrated model was named as TRAM (Technology Readiness-Acceptance Model). This integrated model has been used by several researcher such as Lin, Shih, Sher, and Wang (2005), and Walczuch, Lemmink, and Streukens (2007) while linkages between perceived usefulness, perceived ease of use, and actual use of technology are well established by Davis (1989), Venkatesh \& Davis (2000) and ; Schepers \& Wetzels (2007). Another researcher also use TRAM are :

1. Kuang-Ming Kuo, Chung-Feng Liu and Chen-Chung Ma(2013), with their research title: An investigation of the effect of nurses'technology readiness on the acceptance of mobile electronic medical record systems.

2. Rita Walczuch, Jos Lemmink, Sandra Streukens (2006), with their research title: The effect of service employees' technology readiness on technology acceptance.

3. Murat Esen, Nihat Erdogmu, (2014), with their research title: Effects of Technology Readiness On Technology Acceptance In E-HRM: Mediating Role of Perceived Usefulness. 
4. Anders Husa, Magnus Kvale (2009), with their research title: "The TRAM Framework in a Social Media Context - Measuring Attitudes Towards ConsumerCompany Interaction" A Study of Norwegian Social Media Users.

5. Mimin Nur Aisyah, Mahendra Adhi Nugroho, Endra Murti Sagoro (2013), with their research title: Pengaruh Technology Readiness Terhadap Penerimaan Teknologi komputer Pada UMKM di Yogyakarta.

6. Jui-yen Yen. (2014), with research title: Perspectives from the TRAM Model on Adopting e-Learning: An Analysis of the Chain and Franchise Industry in Taiwan.

7. Nadine Guhr, Tai Loi, Rouven Wiegard, and Michael H. Breitner. (2013), with their research title:Technology Readiness in Customers' Perception and Acceptance of M(obile)-Payment: An Empirical Study in Finland, Germany, the USA and Japan.

8. Issham Ismail, Siti F Bokhare, Siti N Azizan, Nizuwan Azman (2013), with their research title:Teaching via Mobile Phone: a Case Study on Malaysian Teachers' Technology Acceptance and Readiness.

To see the related research, the report study in this paper is implementation of TRAM to AIS, one form type of IT or ICT, which is different from previous studies.

\section{Methodology}

This study aims to reveal how the effects of technology readiness on technology acceptance in the implementation of AIS at ABC university and to see their relationship in TRAM (Technology Readiness-Acceptance Model). This study was a quantitative study using a questionnaire that was developed by Parasuraman for TRI and Davis for TAM. The questionnaire was translated into Indonesian, and given to the respondents to anyone who is concerned and using AIS system consisting of faculties and students at the ABC university

Of the 500 questionnaires distributed, obtained 285 completed questionnaires as well. Data obtained, tested the validity and reliability, using Pearson correlation and Cronbach coefficient, calculations are performed using SPSS version 11.5. For to the TRAM, used pathway analysis, conducted using AMOS 18.The figure of path analysis model is as follows:

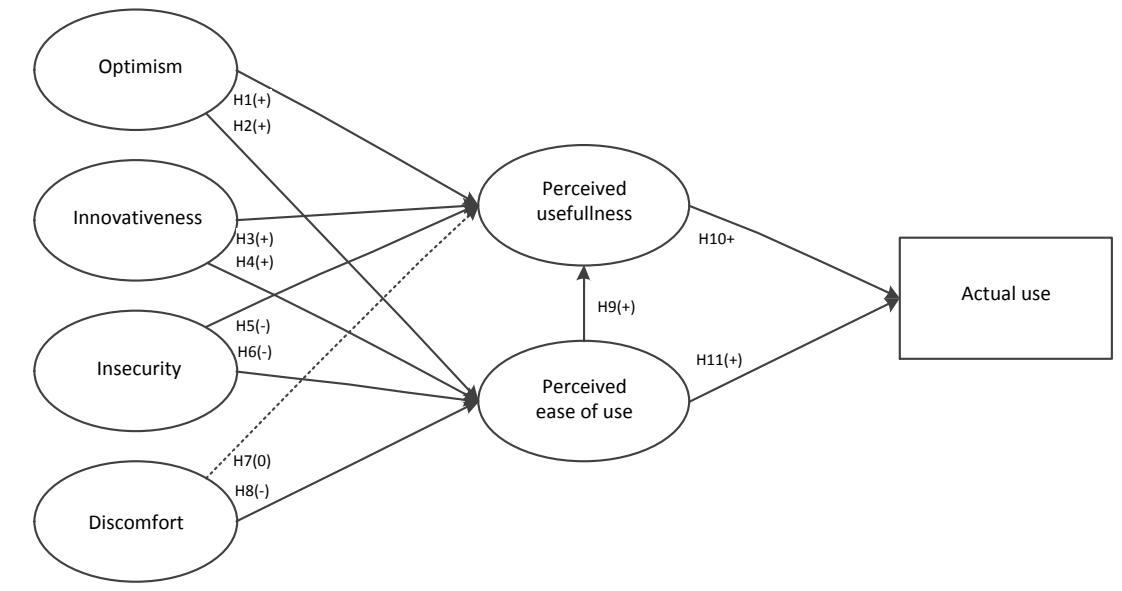

Figure 1. The integrated model (TRAM) with hypothesized relations among study variables.

Acoording to Parasuraman \& Colby (2001) and Tsikriktsis(2004), the optimistic and innovative people to technology as enablers that have positive effects, in general are thought to hold positive attitudes toward new technology and technology use. Therefore, we hypothesized that: 
H1. Optimism is positively related to perceived usefulness.

H2. Optimism is positively related to perceived ease of use.

H3. Innovativeness is positively related to perceived usefulness.

H4. Innovativeness is positively related to perceived ease of use.

Feelings of insecurity related to technology are on the other hand associated with ambiguity and low usage (Parasuraman \& Colby, 2001; Tsikriktsis, 2004). Based on prior research, assume that insecurity predicts lower levels of perceived usefulness and perceived ease of use. Thus, we hypothesize:

H5. Insecurity is negatively related to perceived usefulness.

H6. Insecurity is negatively related to perceived ease of use.

Discomfort, is not expected to have a negative impact on perceived usefulness. One would expect people to see the main value of a system regardless of how they handle it. Still, discomfort is expected to affect perceived ease of use. A system that is not manageable is more likely to be a non user-friendly system. Thus, we hypothesize:

H7. Discomfort is not significantly related to perceived usefulness.

H8. Discomfort is negatively related to perceived ease of use.

The effects of perceived ease of use contributes to perceived usefulness have done by (King \& He, 2006; Lin et al., 2005; McFarland \& Hamilton, 2004; Schepers \& Wetzels, 2007; Venkatesh, 2000; Yang \& Yoo, 2004). Based on the assumptions that some userfriendly applications could be perceived as useful, but not all useful applications are userfriendly. Thus, we hypothesize:

H9. Perceived ease of use is positively related to perceived usefulness.

According to Davis (1989) the main contributor to actual use of a new technology is its perceived usefulness. Hence, people mostly adopt new technologies based on their functions, rather than based on practically. Users are, for instance, willing to adopt a difficult system if it captures a critical function. However, in practical terms, about $90 \%$ of research done on TAM also shows direct effects of perceived ease of use on actual use (Schepers \& Wetzels, 2007). Thus, we hypothesize:

H10. Perceived usefulness is positively related to actual use.

H11. Perceived ease of use is positively related to actual use.

\section{Result and Discussion}

Before performing the analysis on the model TRI and TAM in TRAM (technology readinessacceptance model), the data obtained from 285 respondents to test the validity and reliability, which processing the data using SPSS 11.5 version and AMOS 18. Results of the validity and reliability testing in Table-1.

Table-1. Validity dan Reliabillty test

\begin{tabular}{|c|c|c|c|c|c|}
\hline $\begin{array}{l}\text { Variables } \\
\text { Optimism }\end{array}$ & $\begin{array}{c}\text { Pearson } \\
\text { Correlation }\end{array}$ & $\begin{array}{l}\text { Variable } \\
\text { Innovativeness }\end{array}$ & $\begin{array}{c}\text { Pearson } \\
\text { Correlation }\end{array}$ & $\begin{array}{c}\text { Variable } \\
\text { Discomfort }\end{array}$ & $\begin{array}{c}\text { Pearson } \\
\text { Correlation }\end{array}$ \\
\hline OP1 &, $511\left(^{\star *}\right)$ & IN1 &, $536\left({ }^{* \star}\right)$ & DIS1 & ,228(**) \\
\hline OP2 &, $318\left(^{* \star}\right)$ & IN2 & ,624(**) & DIS2 & ,266(**) \\
\hline OP3 &, $\left.5900^{(*}\right)$ & IN3 &, $594\left({ }^{* *}\right)$ & DIS3 &, $539\left(^{* *}\right)$ \\
\hline OP4 &, $\left.398{ }^{(* *}\right)$ & IN4 &, $545\left({ }^{* *}\right)$ & DIS4 & $468\left(^{* *}\right)$ \\
\hline OP5 &, $636\left(^{(* *}\right)$ & IN5 & ,625(**) & DIS5 &, $356\left({ }^{* *}\right)$ \\
\hline OP6 &, $563\left({ }^{* *}\right)$ & IN6 &, $574\left({ }^{* *}\right)$ & DIS6 &, $\left.4611^{* *}\right)$ \\
\hline OP7 &, $650\left(^{* *}\right)$ & IN7 &, $561\left(^{* *}\right)$ & DIS7 &, $374\left({ }^{* *}\right)$ \\
\hline OP8 &, $586\left(^{(* \star}\right)$ & Alpha &, 7606 & DIS8 &, $479\left({ }^{* *}\right)$ \\
\hline OP9 & ,642(**) & & & DIS9 & ,451(**) \\
\hline OP10 & ,614( $\left.{ }^{* *}\right)$ & & & DIS10 & ,432(**) \\
\hline
\end{tabular}




\begin{tabular}{|c|c|c|c|c|c|}
\hline Alpha &, 8618 & & & Alpha &, 7016 \\
\hline $\begin{array}{l}\text { Variable } \\
\text { Insecurity }\end{array}$ & $\begin{array}{c}\text { Pearson } \\
\text { Correlation }\end{array}$ & $\begin{array}{l}\text { Variable } \\
\text { Perceived } \\
\text { usefulness }\end{array}$ & $\begin{array}{l}\text { Pearson } \\
\text { Correlation }\end{array}$ & $\begin{array}{l}\text { Variable } \\
\text { perceived } \\
\text { ease of use }\end{array}$ & $\begin{array}{l}\text { Pearson } \\
\text { Correlation }\end{array}$ \\
\hline INS1 &, $340\left(^{* *}\right)$ & PU1 &, $522\left({ }^{* \star}\right)$ & PE1 &, $679\left(^{* \star}\right)$ \\
\hline INS2 &, $\left.600{ }^{* *}\right)$ & PU2 &, $\left.539{ }^{* \star}\right)$ & PE2 &, $630\left(^{* *}\right)$ \\
\hline INS3 &, $349\left(^{* *}\right)$ & PU3 &, $600\left(^{* *}\right)$ & PE3 & ,485( $\left.{ }^{* \star}\right)$ \\
\hline INS4 &, $600\left(^{* *}\right)$ & PU4 &, $589\left({ }^{* *}\right)$ & PE4 &, $597\left({ }^{* *}\right)$ \\
\hline INS5 &, $295\left(^{* \star}\right)$ & PU5 &, $577\left({ }^{\star \star}\right)$ & PE5 &, $514\left({ }^{* \star}\right)$ \\
\hline INS6 &, $622\left(^{* \star}\right)$ & PU6 &, $504\left({ }^{\star \star}\right)$ & PE6 &, $641\left(^{* \star}\right)$ \\
\hline INS7 &, $457\left(^{* \star}\right)$ & Alpha &, 6225 & Alpha &, 6925 \\
\hline INS8 &, $600\left(^{* *}\right)$ & & & & \\
\hline INS9 &, $481\left({ }^{* *}\right)$ & & & & \\
\hline Alpha &, 7529 & & & & \\
\hline
\end{tabular}

** Correlation is significant at the 0.01 level (2-tailed).

* Correlation is significant at the 0.05 level (2-tailed).

In table 1, the validity in the form of Pearson correlation, where for each indicator of Technology readiness and technology acceptance variables significant at the 0.01 confidence level. Thus the data obtained are valid. In addition, the reliability values for each variable group still shows the reliability value greater than 0.6 , so that the data obtained is reliable. Before the path analysis, to analyze the average value of each variable in the TRAM, which support the data in Table-2.

Table-2 The average value of variables

\begin{tabular}{|l|l|}
\hline Variable & average \\
\hline Optimism & 3,515 \\
\hline Innovativeness & 3,480 \\
\hline Discomfort & 3,538 \\
\hline Insecurity & 3,558 \\
\hline Perceived easy of use & 3,527 \\
\hline Perceived usefulness & 3,589 \\
\hline Actual use & 3,632 \\
\hline
\end{tabular}

In Table 2, the respondents, indicating the nature of optimism and innovativeness are quite high (> 2.5), so they have the mental enabler high enough. While the average value of discomfort and Insecurity can be said is also quite high (> 2.5), so they have a high enough inhibitor properties. Thus their readiness technology not too high / good in receiving AIS technology. For Perceived easy of use, with the average value of 3.527, meaning their beliefs for easy use of technology is quite high. The average value of Perceived usefulness is 3.589, quite high also, meaning they have a fairly high confidence that the use of IT technology, it gives many useful. The value of actual Use is 3.632, can be interprete quite high, meaning that the frequency of their use of IT technology is quite high. However, these variables will be tested in the TRAM. Further,the path analysis using AMOS 18. Figure 2 and table-3 shows the results of the path analysis. 


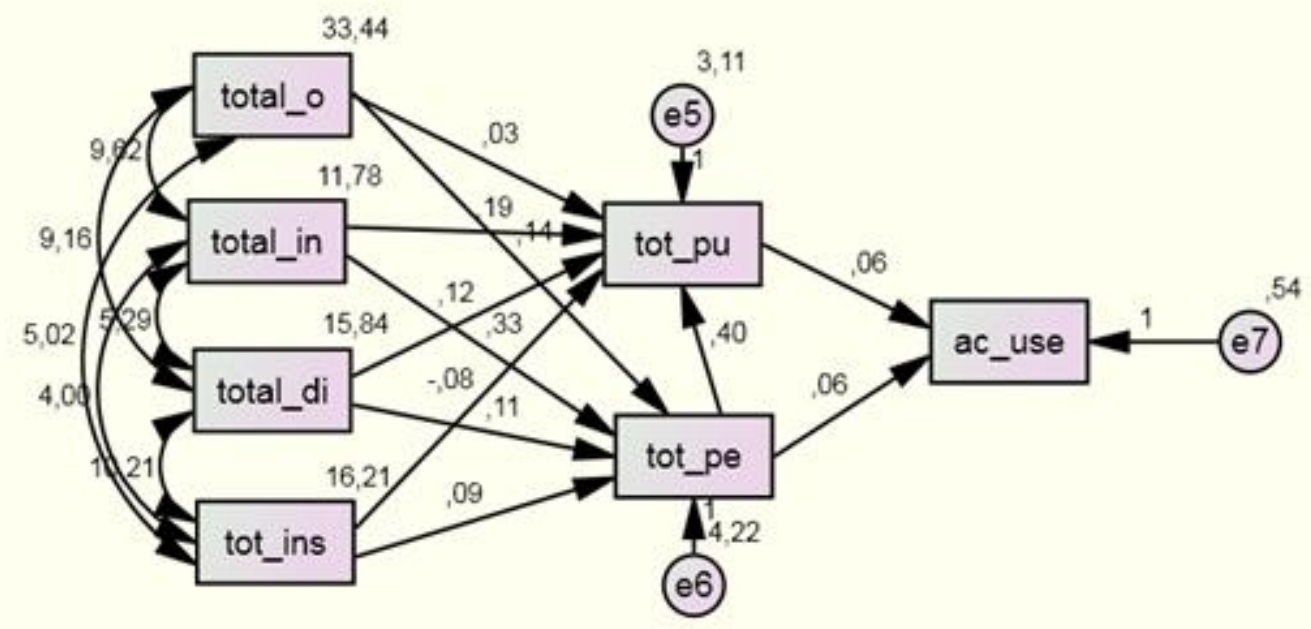

Figure-2. Estimation model

The values of Regression weight that show in the figure-2, presented at table-3.

Table-3. Regression Weights and Hypothesis conclusions

\begin{tabular}{|l|l|l|r|r|r|r|l|l|}
\hline & & Estimate & S.E. & C.R. & P & Label & \\
\hline $\begin{array}{l}\text { Perceived } \\
\text { easy of use }\end{array}$ & $<---$ & Optimism &, 141 &, 025 & 5,629 & $* * *$ & par_5 & $\begin{array}{l}\text { H2 proved positive and } \\
\text { significant }\end{array}$ \\
\hline $\begin{array}{l}\text { Perceived } \\
\text { easy of use }\end{array}$ & $<---$ & Innovativeness &, 334 &, 042 & 7,947 & $* * *$ & par_6 & $\begin{array}{l}\text { H 4proved positive and } \\
\text { significant }\end{array}$ \\
\hline $\begin{array}{l}\text { Perceived } \\
\text { easy of use }\end{array}$ & $<---$ & Discomfort &, 111 &, 043 & 2,598 &, 009 & par_7 & $\begin{array}{l}\text { H8 is not proved, because } \\
\text { the positive and significant }\end{array}$ \\
\hline $\begin{array}{l}\text { Perceived } \\
\text { easy of use }\end{array}$ & $<---$ & Insecurity &, 094 &, 039 & 2,368 &, 018 & par_8 & $\begin{array}{l}\text { H6 not proved negative, } \\
\text { but significant }\end{array}$ \\
\hline $\begin{array}{l}\text { Perceives of } \\
\text { usefullness }\end{array}$ & $<---$ & Optimism &, 025 &, 023 & 1,107 &, 268 & par_1 & $\begin{array}{l}\text { H1 proven positive, but not } \\
\text { significant }\end{array}$ \\
\hline $\begin{array}{l}\text { Perceives of } \\
\text { usefullness }\end{array}$ & $<---$ & Innovativeness &, 186 &, 040 & 4,651 & $* * *$ & par_2 & $\begin{array}{l}\text { H3 proved positive and } \\
\text { significant }\end{array}$ \\
\hline $\begin{array}{l}\text { Perceives of } \\
\text { usefullness }\end{array}$ & $<---$ & Discomfort &, 124 &, 037 & 3,327 & $* * *$ & par_3 & $\begin{array}{l}\text { H7 was not proved, } \\
\text { because significant }\end{array}$ \\
\hline $\begin{array}{l}\text { Perceives of } \\
\text { usefullness }\end{array}$ & $<---$ & Insecurity &,- 076 &, 034 & $-2,213$ &, 027 & par_4 & $\begin{array}{l}\text { H5 proved negative and } \\
\text { significant }\end{array}$ \\
\hline $\begin{array}{l}\text { Perceives of } \\
\text { usefullness }\end{array}$ & $<---$ & $\begin{array}{l}\text { Perceived easy } \\
\text { of use }\end{array}$ &, 397 &, 051 & 7,783 & $* * *$ & par_11 & $\begin{array}{l}\text { H9 proved positive and } \\
\text { significant }\end{array}$ \\
\hline actual_use & $<---$ & $\begin{array}{l}\text { Perceives of } \\
\text { usefullness }\end{array}$ &, 062 &, 023 & 2,682 &, 007 & par_9 & $\begin{array}{l}\text { H10 proved positive and } \\
\text { significant }\end{array}$ \\
\hline actual_use & $<---$ & $\begin{array}{l}\text { Perceived easy } \\
\text { of use }\end{array}$ &, 064 &, 020 & 3,153 &, 002 & par_10 & $\begin{array}{l}\text { H11 proved positive and } \\
\text { significant }\end{array}$ \\
\hline
\end{tabular}

Variable Optimism, Innovativeness, Discomfort and Insecutrity positive effect on Perceived ease of use, indicated by the p-value less than 0.05 or the value of CR (Critical Ratio) is greater than two. Optimism variable does not provide significant effect on Perceived 
usefulness. Innovativeness and discomfort variables are significant positive effect on the variable Perceived usefulness, while variable Insecurity in significant negative effect on the variable Perceived usefulness. Variables Perceived ease of use, are significant positive effect on the variable Perceived usefulness. Variables Perceived usefulness and variables of Perceived ease of use significant positive effect on the variable Actual use. Of the 11 hypothesis 7 hypothesis proved while 4 hypothesis are not proven. Variables that are not proven effect are:

1. Discomfort on perceived ease of use, hypothesised (H8) is negatively related, but in this study associated positive and significant. This means that, even if they feel uncomfortable in technology, they still have an confidence easy in using technology. The more uncomfortable, it is increasingly convinced that the technology is easy to use.

2. Insecurity of the perceived ease of use, hypothesised (H6) is negatively related, but in this study associated positive and significant. This means, the more insecure in using technology, they remain confident easy to use technology. The more insecure, they become convinced that using it will be easy.

3. Optimism on the perceived usefulness, hypothesised (H6) are positively related, but his will in this study relate positively but not significant. So in this case the nature of the respondent that optimism had no effect on perceived usefulness.

4. Discomfort against Perceived of usefullness, hypothesised (H7) not significant related, but in this study associated positive and significant. This means that, even if they feel uncomfortable, they remain confident that the use of technology will be very useful. Increasing discomfort, increasingly convinced that the use of technology will be very useful.

To see how the contribution of each variable, using the value in standardization, is presented in Figure 3 and Table-4.

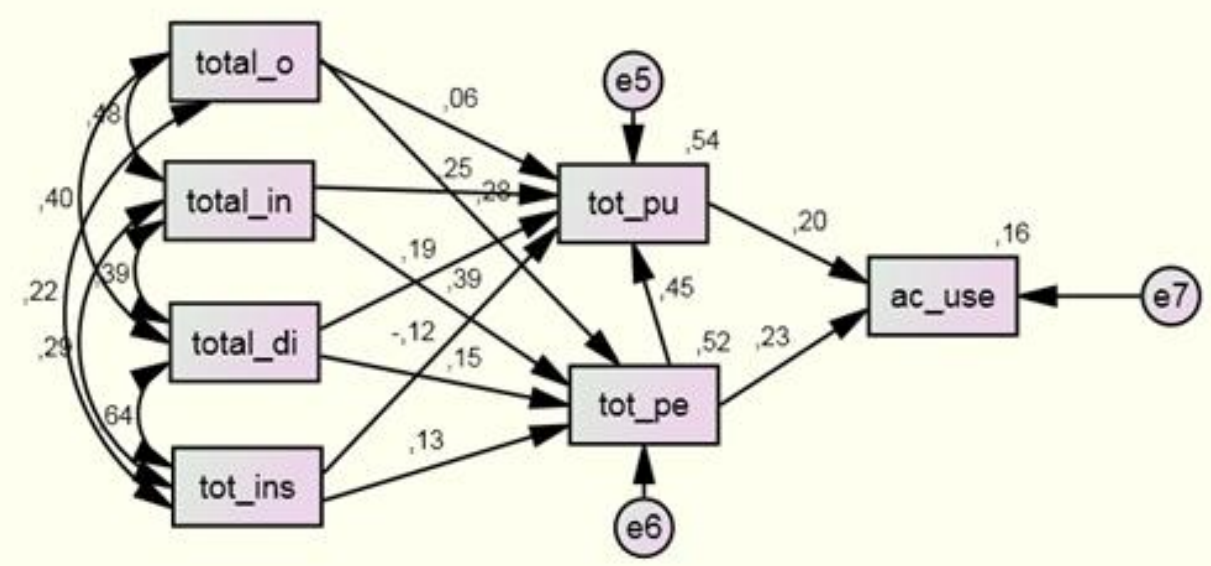

Figure-3. Path Analysis model with Standardized estimate

Table-4. Standardized Regression Weights

\begin{tabular}{|l|l|l|r|}
\hline & & & Estimate \\
\hline Perceived easy of use & $<--$ & Optimism &, 276 \\
\hline Perceived easy of use & $<---$ & Innovativeness &, 388 \\
\hline
\end{tabular}




\begin{tabular}{|l|r|l|r|}
\hline & & & Estimate \\
\hline Perceived easy of use & $<---$ & Discomfort &, 150 \\
\hline Perceived easy of use & $<---$ & Insecurity &, 128 \\
\hline Perceives of usefullness & $<---$ & Optimism &, 056 \\
\hline Perceives of usefullness & $<---$ & Innovativeness &, 246 \\
\hline Perceives of usefullness & $<---$ & Discomfort &, 190 \\
\hline Perceives of usefullness & $<---$ & Insecurity &,- 118 \\
\hline Perceives of usefullness & $<---$ & Perceived easy of use &, 452 \\
\hline actual_use & $<---$ & Perceives of usefullness &, 200 \\
\hline actual_use & $<---$ & Perceived easy of use &, 235 \\
\hline
\end{tabular}

Technology readiness variables that have the greatest effect on the Perceived ease of use variable is the innovativeness of 0.388 ; the second effect is the optimism of 0,276 ; the third effect is the discomfort of 0,150 ; and the effect of the four is insecurity at 0.128 .

Technology readiness variables that have the greatest effect on the Perceived usefullness variable is innovativeness of 0.246 ; the second effect is the discomfort of 0.190 ; the third effect is the insecurity of -0.118 ; and the fourth is the optimism effect of 0.056

The efect perceived ease of use to the perceived usefullness is 0,452 . The effect Perceived usefullness to the actual use is 0.200 and the effects perceived ease of use to the actual use is 0.235 .

Table-5 Squared Multiple Correlations

\begin{tabular}{|l|r|}
\hline & Estimate \\
\hline tot_pe &, 516 \\
tot_pu &, 536 \\
ac_use &, 159 \\
\hline
\end{tabular}

How the contribution the technology readiness and the technology acceptance, presented in table 5, indicate that the TRI variable which consist of optimism, Innovativeness, Discomfort and Insecurity of $51.6 \%$ has a role in explaining the Perceived ease of use. Likewise, TRI variables that consist of optimism, Innovativeness, Discomfort and Insecurity of $53.6 \%$ have a role in explaining Perceived usefulness. Furthermore, perceived ease of use and Percerived usefulness explained $15.9 \%$ of the Actual use.

Furthermore, related to analyze total effects, direct and indirect effects, presented in table-6, table-7 and table-8.

Table-6 Standardized Total Effects

\begin{tabular}{|l|rrrrrr|}
\hline & insecurity & Discomfort & innovativenss & optimism & PEOU & PU \\
\hline PEOU &, 128 &, 150 &, 388 &, 276 &, 000 &, 000 \\
PU &,- 060 &, 258 &, 421 &, 181 &, 452 &, 000 \\
Actual_use &, 018 &, 087 &, 175 &, 101 &, 325 &, 200 \\
\hline
\end{tabular}

Analysis of total effect of each variables in table-6, with still consider to the result of hypothesis analysis above : 
1. Insecurity does not give the total effect on Perceived easy of use, but it will to give the total effect on the perceived usefulness of -0.060 and to the actual use amounted to 0,018 .

2. Discomfort does not give the total effect on the perceived easy of use and perceived usefulness, but it gives the total effect on the actual use of 0,087 .

3. Innovativeness give total effect on Perceived easy of use of 0.388 , the perceived usefulness of 0.421 and the actual use of 0.175 .

4. Optimism does not give the total effect on perceived usefulness, but the total effect on the perceived easy of use amounted to 0,276 and the actual use amounted to 0,101 .

5. Perceived easy of use gives the total effect on perceived usefulness 0,452 .

6. Perceived easy of use gives the total effect on the actual use of 0.325

7. Perceived usefulness gives the total effect on the actual use of 0.200 .

Table-7 Standardized Direct Effects

\begin{tabular}{|l|rrrrrr|}
\hline & insecurity & Discomfort & innovativenss & optimism & PEOU & PU \\
\hline PEOU &, 128 &, 150 &, 388 &, 276 &, 000 &, 000 \\
PU &,- 118 &, 190 &, 246 &, 056 &, 452 &, 000 \\
Actual_use &, 000 &, 000 &, 000 &, 000 &, 235 &, 200 \\
\hline
\end{tabular}

Analysis of direct effect in table-7, also consider to the result of hypothesis analysis above :

1. Insecurity does not give the direct effect on Perceived easy of use, but it will to give the direct effect on the perceived usefulness of -0.118 and nothing direct effect to actual use.

2. Discomfort does not give the direct effect on the perceived easy of use and also to perceived usefulness, nothing direct effect on the actual use.

3. Innovativeness give direct effect on Perceived easy of use of 0.388 , to the perceived usefulness of 0.246 and nothing direct effect on the actual use.

4. Optimism does not give the direct effect on perceived usefulness, but the direct effect on the perceived easy of use amounted to 0,276 and nothing direct effect on the actual use..

5. Perceived easy of use gives the direct effect on perceived usefulness 0,452 .

6. Perceived easy of use gives the direct effect on the actual use of 0.325

7. Perceived usefulness gives the direct effect on the actual use of 0.200

8. TR nothing direct effect to actual use

Table-8 Standardized Indirect Effects

\begin{tabular}{|l|rrrrrr|}
\hline & insecurity & Discomfort & innovativenss & optimism & PEOU & PU \\
\hline PEOU &, 000 &, 000 &, 000 &, 000 &, 000 &, 000 \\
PU &, 058 &, 068 &, 176 &, 125 &, 000 &, 000 \\
Actual_use &, 018 &, 087 &, 175 &, 101 &, 090 &, 000 \\
\hline
\end{tabular}

Analysis of indirect effect in table-8, also consider to the result of hypothesis analysis above :

1. Insecurity does not give the indirect effect on Perceived easy of use, but it will to give the indirect effect on the perceived usefulness of 0,058 and to the actual use of 0,018 .

2. Discomfort does not give the indirect effect on the perceived easy of use and also to perceived usefulness, give indirect effect on the actual useof 0,087 . 
3. Innovativeness nothing indirect effect on Perceived easy of use, to the perceived usefulness of 0.176 and indirect effect on the actual use of 175 .

4. Optimism does not give the indirect effect on perceived usefulness, nothing indirect effect on the perceived easy of use and indirect effect on the actual use of 0,101

5. Perceived easy of use does not gives the indirect effect on perceived usefulness.

6. Perceived easy of use gives the indirect effect on the actual use of 0.09 .

7. Perceived usefulness nothing the indirect effect on the actual use.

8. TR nothing indirect effect to perceived easy of use, but have indirect effect to perceived usefulness and actual use.

Based on all those above analysis, in the state of AIS implementation at ABC university, corresponding to the figure of path analysis, all variables have the total effect to all variables, except the variables are not proven their hypothesis, while the direct effect, the varibles just effect to the variables infront of them, indirect nothing of TR variable have the indirect effect to perceived easy of use. In this case, the user of AIS which consist of lecturers and students, they have discomfort and insecurity personality that contradictive to the theory. They have positive personality to the perceived easy of use. But the belief to use the AIS easy, still quite high. In this case no problem for them to use the AIS with the positive inhibitor of their personality. In case they have optimism positive effect to perceived usefulness but not significant, even though their optimism quite high, the belief to AIS is usefulness, still quite high. And in case the user of AIS have discomfort personality with related significant to the perceived usefulness, the belief to AIS is usefulness, still quite high too. So, no matter for the university, the instrument of AIS is quite high its usefulness. In general, although the lecturers and students have the inhibitor quite high to technology readiness, the acceptance of AIS is still quite high. And their actual use to AIS is still quite high.

\section{Conclusions}

ABC university has implemented AIS. This study to reveal how the related and the effect of technology readiness to technology acceptance in using AIS. The result of this study, variable Optimism, Innovativeness, Discomfort and Insecutrity have positive effect on Perceived ease of use, indicated by the p-value less than 0.05 or the value of CR (Critical Ratio) is greater than two. Optimism variable does not provide significant effect on Perceived usefulness. Innovativeness and discomfort variables are significant positive effect on the variable Perceived usefulness, while variable Insecurity in significant negative effect on the variable Perceived usefulness. Variables Perceived ease of use, are significant positive effect on the variable Perceived usefulness. Variables Perceived usefulness and variables of Perceived ease of use are positive and significant effect on the variable Actual use. Of the 11 hypothesis 7 hypothesis proved while 4 hypothesis is not proven.

\section{References}

Anders Husa, Magnus Kvale (2009). "The TRAM Framework in a Social Media Context Measuring Attitudes Towards Consumer-Company Interaction” A Study of Norwegian Social Media Users. Thesis Master of Science in Strategic Marketing Management. Oslo. Retrived from http://andershusa.files.wordpress.com/2010/03/master-thesisfinal.pdf, 4 des 2014. 
Burton-Jones, A., \& Hubona, G. S. (2006). The mediation of external variables in the technology acceptance model. Information \& Management, 43, 706-717. doi:10.1016/j.im.2006.03.007

Davis, F. D. (1989). Perceived usefulness, perceived ease of use, and user acceptance of information technology. MIS Quarterly, 13, 319-340. doi:10.2307/249008

Davis, D., Bagozzi, R. P., \& Warshaw, P. R. (1989). User acceptance of computer technology: A comparison of two theoretical models. Management Science, 35, 9821003. doi:10.1287/mnsc.35.8.982

Fishbein, M., \& Ajzen, I. (1975). Belief, attitude, intention, and behavior: An introduction to theory and research. Reading, MA: Addison-Wesley.

Issham Ismail, Siti F Bokhare, Siti N Azizan, Nizuwan Azman (2013).Teaching via Mobile Phone: a Case Study on Malaysian Teachers' Technology Acceptance and Readiness.

School of Distance Education Universiti Sains Malaysia, Malaysia. Journal of Educators Online, v10 n1 Jan 2013. Retrived from: http://eric.ed.gov/?id=EJ1004895, 4 des 2014.

King, W. R., \& He, J. (2006). A meta-analysis of the technology acceptance model. Information \& Management, 43, 740-755. doi:10.1016/j.im.2006.05.003

Kuang-Ming Kuo, Chung-Feng Liu and Chen-Chung Ma(2013).An investigation of the effect of nurses'technology readiness on the acceptance of mobile electronic medical record systems. Kuo et al. BMC Medical Informatics and Decision Making 2013. Retrived from http://www.biomedcentral. com/1472-6947/13/88, 4 des 2014.

Lin, C.-H., Shih, H.-Y., \& Sher, P. J. (2007). Integrating technology readiness into technology acceptance: The TRAM model. Psychology \& Marketing, 24, 641-657. doi:10.1002/mar.20177

Lin, C.-H., Shih, H.-Y., Sher, P. J., \& Wang Y.-L. (2005). Consumer adoption of e-service: Integrating technology readiness with the technology acceptance model. Proceedings of PICMET '05: Technology Management: A Unifying Discipline for Melting the Boundaries, Portland, Oregon, USA, 483-488. doi:10.1109/PICMET.2005.1509728

Malhotra, Y., \& Galletta, D. F. (1999). Extending the technology acceptance model to account for social influence: Theoretical bases and empirical validation. Proceedings of the $32^{\text {nd }}$ Hawaii International Conference on System Sciences, Maui, Hawaii, USA, 1-14. doi:10.1109/HICSS.1999.772658

McFarland, D. J., \& Hamilton, D. (2006). Adding contextual specificity to the technology acceptance model. Computers in Human Behavior, 22, 427-447. doi:10.1016/j.chb.2004.09.009

Mimin Nur Aisyah, Mahendra Adhi Nugroho, Endra Murti Sagoro (2013).Pengaruh Technology Readiness Terhadap Penerimaan Teknologi komputer Pada UMKM di Yogyakarta. Jurusan Pendidikan akuntansi, Fakultas Ekonomi. Universitas Negeri Yogyakarta. Retrived from :http://staff.uny.ac.id/sites/default/files/penelitian/Endra \%20Murti\%20Sagoro,\%20S.E.,M.Sc./Pengaruh\%20Technology\%20Readiness\%20Te rhadap\%20Penerimaan\%20Teknologi\%20Komputer\%20pada\%20UMKM\%20di\%20 Yogyakarta.pdf . 25 Januari 2015.

Murat Esen, Nihat Erdogmu, (2014). Effects of Technology Readiness On Technology Acceptance In E-HRM: Mediating Role of Perceived Usefulness. Bilgi Ekonomisi ve Yönetimi Dergisi / 2014 Cilt: IX Say1: Retrived from http://www.beykon.org/dergi/ 2014/SPRING/M.Esen.pdf, 4 des 2014.

Nadine Guhr, Tai Loi, Rouven Wiegard, and Michael H. Breitner. (2013).Technology

Readiness in Customers' Perception and Acceptance of M(obile)-Payment: An

Empirical Study in Finland, Germany, the USA and Japan. Leibniz Universität 
Hannover, Institut für Wirtschaftsinformatik, Hannover, Germany11thInternational Conference on Wirtschaftsinformatik,27thFebruary - 01st March 2013, Leipzig, Germany. Retrived from.http://www.wi2013.de/proceedings/WI2013\%20\%20Track\%201\%20-\%20Guhr.pdf . 25January 2015.

Parasuraman, A. (2000). Technology readiness index (TRI): A multiple-item scale to measure readiness to embrace new technologies. Journal of Service Research, 2, 307-320. doi:10.1177/109467050024001

Parasuraman, A., \& Colby, C. L. (2001). Techno-ready marketing: How and why your customers adopt technology. New York: Free Press.

Rorim Panday, John Tampil Purba. (2015). Lecturers and Students Technology Readiness in implementing Services Delivery of Academic Information System In Higher Education Institution: A Case Study. Paper for 4th International Conference on Soft Computing, Intelligent System and Information Technology 2015. Bali- Indonesia, 11-14 March 2015.

Rita Walczucha, Jos Lemminkb , Sandra Streukens (2006). The effect of service employees' technology readiness on technology acceptance. Department of Accounting and Information Management, Faculty of Economics and Business Administration, Postbus 616, Maastricht University, The Netherlands. Elsevier, Information \& Management 44 (2007) 206-215. Retrived from http://arno.unimaas.nl/show.cgi?fid=10659, 4 des 2014.

Schepers, J., \& Wetzels, M. (2007). A meta-analysis of the technology acceptance model: Investigating subjective norm and moderation effects. Information \& Management, 44, 90-103. doi:10.1016/j.im.2006.10.007

Tsikriktsis, N. (2004). A technology readiness-based taxonomy of costumers: A replication and extension. Journal of Service Research 7, 42-52. doi:10.1177/1094670504266132

Venkatesh, V. (2000). Determinants of perceived ease of use: Integrating control, intrinsic motivation, and emotion into the technology acceptance model. Information Systems Research, 11, 342-365. doi:10.1287/isre.11.4.342.11872

Venkatesh, V., \& Davis F. D. (2000). A theoretical extension of the technology acceptance model: Four longitudinal field studies. Management Science, 46, 186-204. doi:10.1287/mnsc.46.2.186.11926

Walczuch, R., Lemmink, J., \& Streukens, S. (2007). The effect of service employees' technology readiness on technology acceptance. Information \& Management, 44, 206215. doi:10.1016/j.im.2006.12.005

Yang, H.-D., \& Yoo, Y. (2004). It's all about attitude: Revisiting the technology acceptance model. Decision Support Systems, 38, 19-31. doi:10.1016/S0167-9236(03)00062-9

Yi, M. Y., \& Hwang, Y. (2003). Predicting the use of web-based information systems: Selfefficacy, enjoyment, learning goal orientation, and the technology acceptance model. International Journal of Human-Computer Studies, 59, 431-449. doi:10.1016/S10715819(03)00114-9

Jui-yen Yen. (2014). Perspectives from the TRAM Model on Adopting e-Learning: An Analysis of the Chain and Franchise Industry in Taiwan. Retrived from : http://140.131.112.6:8080/ir/bitstream/987654321/2032/2/TRAM\%E6\%A8\%A1\%E5\% BC\%8F\%E8\%A7\%80\%E9\%BB\%9E\%E4\%B8\%8B\%Е8\%87\%BA\%E7\%81\%A3\%Е9 \%80\%A3\%Е9\%8E\%96\%E5\%8A\%A0\%Е7\%9B\%9F\%E7\%94\%A2\%E6\%A5\%AD\%E 6\%8E\%A1\%E7\%94\%A8\%E6\%95\%B8\%E4\%BD\%8D\%E5\%AD\%B8\%Е7\%BF\%92\% E4\%B9\%8B\%E5\%AF\%A6\%E8\%AD\%89\%E5\%88\%86\%E6\%9E\%90.pdf. 25januari 2015 , 